\title{
SPATIAL DISTRIBUTION OF GROUNDWATER SALINITY AT PERGAMINO - ARRECIFES ZONE (BUENOS AIRES PROVINCE, ARGENTINA)
}

\author{
Claudia M. Sainato ${ }^{1}$ and Beatriz N. Losinno ${ }^{2}$ \\ Recebido em 27 abril, 2006 / Aceito em 31 agosto, 2006 \\ Received on April 27, 2006 / Accepted on August 31, 2006
}

\begin{abstract}
The application of irrigation at the NE of Buenos Aires Province, Argentina, demands the knowledge of groundwater features, in particular salinity, in order to avoid unsuccessful drillings and to prevent from deterioration of soils. Some previous large scale studies have shown the presence of salty groundwater at different depths at close sites, and well information is scarce. The scope of this work is to determine the depth and thickness of the aquifers of the zone and to obtain the spatial distribution of groundwater salinity. Vertical Electrical Soundings were performed and the continuity of the aquifers was analyzed along four transects integrating previous results. Geostatistical methodology was used to obtain the spatial variability of electrical resistivity of the Pampeano aquifer, which increases to the east. This analysis was also performed to determine the depth of the fresh-salty water interface which deepens at the left margin of Pergamino river and to the SE direction. A transition zone was found, at SE of the study area, west of Arrecifes city, where the fresh salty water interface and the water table level deepens abruptly.
\end{abstract}

Keywords: groundwater salinity; Buenos Aires Province (Argentina), spatial variability, geoelectrical soundings.

RESUMO. A aplicação da irrigação no Nordeste da Província de Buenos Aires, Argentina, requer o conhecimento das características da água subterrânea, em particular a salinidade, para evitar perfurações infrutíferas e deterioração do solo. Alguns estudos prévios em grande escala tem mostrado a presença da água subterrânea salina em diferentes profundidades em locais próximos, e a informação sobre perfurações é escassa. 0 objetivo do trabalho é a determinação da profundidade e espessura dos aqüíferos da zona e obter a distribuição espacial da salinidade da água subterrânea. Foram realizadas Sondagens Elétricas Verticais e a continuidade dos aqüíferos foi analisada ao longo de quatro "transectas" integrando resultados prévios. A metodologia geo-estatística foi usada para obter a variabilidade espacial da resistência elétrica do aqǘfero Pampeano que aumenta para Leste. Esta análise também foi realizada para determinar a profundidade da interface da água doce-água salina, a qual, se aprofunda pela margem esquerda do Pergamino e segue na direção sudeste. Encontrou-se uma zona de transição no sudeste da área do estudo, a oeste da localidade de Arrecifes, onde a interface água doce-água salina e o nível freático se aprofundam abruptamente.

Palavras-chave: salinidade da água subterrânea, Província de Buenos Aires, distribuiçãa espacial, Sondagens Elétricas Verticais.

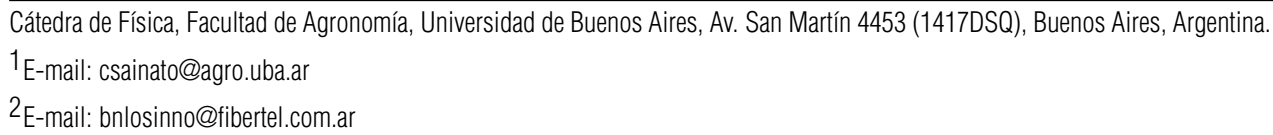




\section{INTRODUCTION}

The study area is placed at the NE of Buenos Aires Province, Argentina, the so-called Humid Pampa (Figure 1). This is a very rich agriculture zone where groundwater resources are used for irrigation and for animal and human consumption. The increasing application of irrigation may cause the sustainable development of the resource to run a risk if the characteristics of groundwater are not well known. The recharge of Pergamino river, which flows to the Arrecifes river, takes place at the area of Juncal swamp. The most recent and shallow hydrogeological Formations are the sandy Puelche Formation (Upper Tertiary-Quaternary) and the silty-clayey and clayey-silty sediments of the Pampeano Formation (Quaternary) and the Post-Pampeano (Santa Cruz, 1994). The Pampeano unit contains the phreatic aquifer and some deeper semiconfined aquifers with low salinity water. The Puelche sands have variable water salinity depending on the zone (Santa Cruz, 1987) with saline residual values greater than $2 \mathrm{~g} \mathrm{~L}^{-1}$ near Pergamino and lower than $0.5 \mathrm{~g} \mathrm{~L}^{-1}$ at the Arrecifes zone. The transition between fresh and salty water is an interface, within the Pampeano or the Puelche aquifer, which was found between 50 and $100 \mathrm{~m}$ depth near Pergamino zone. These are regional results which do not represent the local variations within the Pergamino river basin. Sainato et al. (2003) carried out seventeen Vertical Electrical Soundings (VES) at the NW zone of Figure 1 (VES 1 to 17). At the west of Pergamino city, the top of a highly conductive layer identified with the fresh-salty water interface was found below $28 \mathrm{~m}$ depth at the right margin of Pergamino river and at $60 \mathrm{~m}$ depth at the left one, deepening towards NE. Similar results were found through Audio Magnetotelluric soundings (Sainato et al., 2000) indicating the deepening of the fresh-salty water interface in the same direction. The recharge of free aquifer coincides with high topographic levels while the discharge is mainly towards the Pergamino river. Groundwater electrical conductivity is greater than $1800 \mu \mathrm{S} \mathrm{cm}^{-1}$ at discharge zones with fine texture soils or, at some places, where the hydraulic gradient is very small, increasing water time of residence. Water of lower salinity may be found at the recharge areas or at transition zones with moderate hydraulic gradient. Variations in the sedimentary sequence were found at near sites, so it is of interest to know if these lateral discontinuities are present over a larger zone. Since the Pampeano and Puelche aquifers are the main source of water in this rural area, one of the points to avoid unsuccessful drillings and upraise of saline water is to know the depth to the fresh-salty water interface.

At the study area, there are no references of geological sec- tions and there are a few wells whose lithological descriptions were used for geophysical interpretation. The scope of this work is to determine the depth and thickness of the aquifers at the Pergamino-Arrecifes zone, integrating previous results, and obtain the spatial distribution of groundwater conductivity.

In order to understand the regional features of these aquifers it was necessary to perform new VES at the SE zone (near Arrecifes city), covering the whole area of the hydrogeological basin of Pergamino river. It is interesting to know whether there is a correlation in the behavior of the aquifer properties over a larger area.

An increasing amount of literature is devoted to geostatistical analysis (Trangmar et al., 1985) applied to variables spatially dependant, such as soil properties and geological features. Marinho \& Vasconcelos (2001) used geostatistical techniques to describe 1D geoelectrical sections. Sun et al. (1995) determined 3-D distribution of hydraulic conductivity and storage coefficient using geostatistics. The geostatistical analysis is based on the spatial correlation that a variable may have over an area, making use of it to interpolate values of the variables where no data are available. Under the hypothesis that the aquifer depth and conductivity may have such a correlation, this approach was applied in this paper to analyze the spatial distribution of them.

\section{GEOLOGICAL AND HYDROGEOLOGICAL SETTING}

The study area is located at the Humid Pampa, at the NE of Buenos Aires Province, at the sub region called Rolling Pampa (Figure 1). It was delimited by the superficial water division of the Pergamino river microbasin, which belongs to the basin of Arrecifes river. The Pergamino river has its recharge at $80 \mathrm{~m}$. a.s.I. at the Juncal swamp, and its superficial drainage direction is SE, with some streams that flow into it.

Table 1 summarizes the characteristics described by Sala (1969), Sala et al. (1983) and Santa Cruz \& Silva Busso (1995), among others, of the Quaternary hydrogeological Formations, including the Pampeano and Puelche aquifer, which constitute the main source of water for agricultural activities and consumption. The Pampeano contains free groundwater and some deeper semiconfined aquifers. It is formed by a sequence of clayey silty sediments, at some levels with more content of sands. It is a multiple aquifer, with permeable and impermeable intercalated levels. Groundwater is, in general, of sodium bicarbonate type. Calcium carbonate is found in Pampean sediments as calcite in different forms: as concretions, veins and hard-pan layers (caliche), which appear at different levels of the Formation (this is what locally is known as "tosca") (Teruggi, 1957). The Pampeano thickness is 


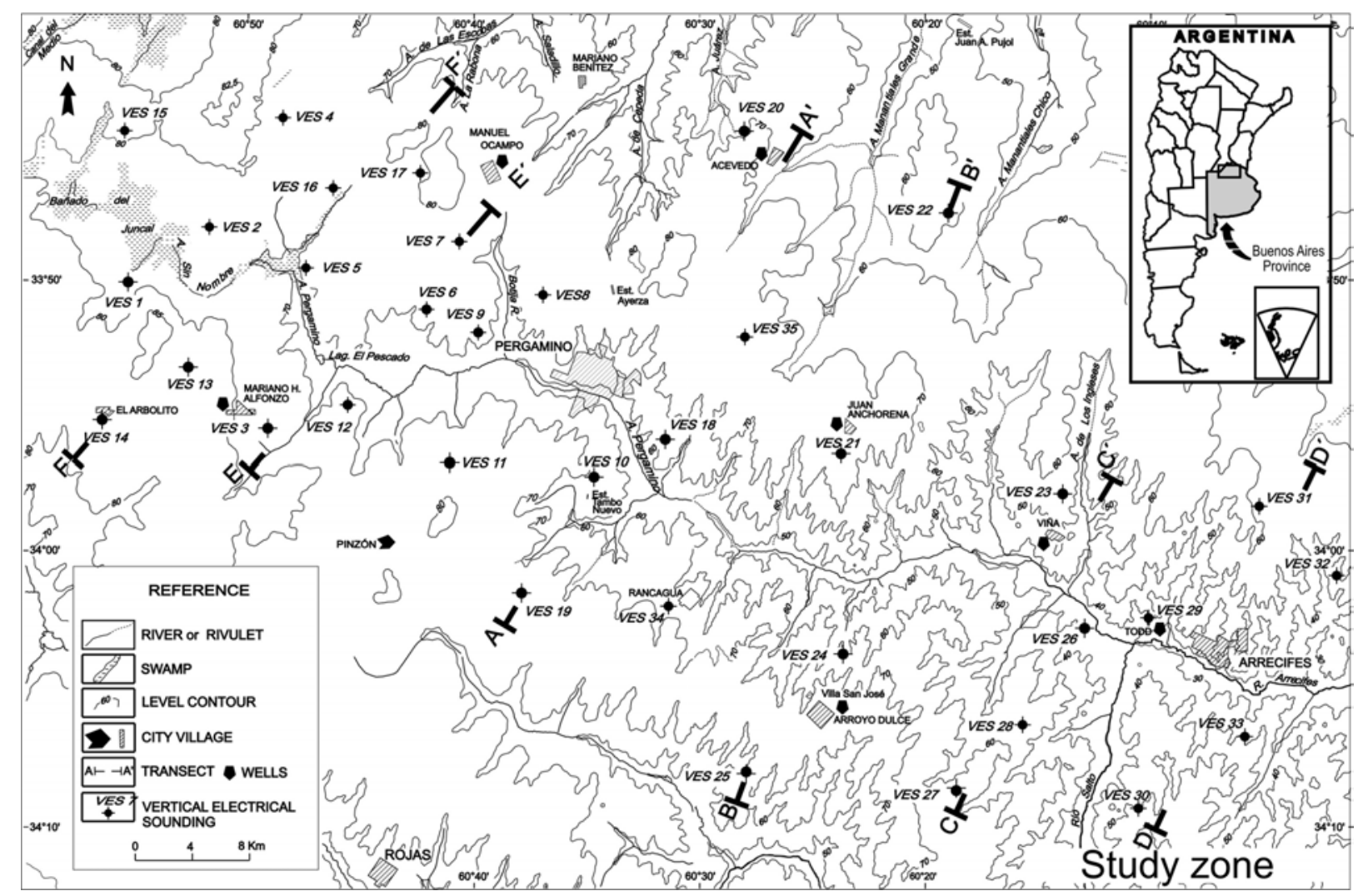

Figure 1 - Study area. Sites of VES and wells are shown. Transects for geoelectrical sections are pointed out.

very variable, between 20 and $120 \mathrm{~m}$. Below, the Puelche aquifer is formed by sands, having bad quality water beyond $25 \mathrm{~km}$ to the west of Pergamino city decreasing its salinity towards the Arrecifes zone (to the east). The transition from fresh water to the underlying salty water is known as an interface within the Pampeano or Puelche aquifer depending on the zone (Santa Cruz \& Silva Busso, 1995). This transition or interface is associated with a decrease of resistivity in the geoelectrical soundings (Santa Cruz, 1987, Sainato et al., 2003). The depth of the top of the Puelche aquifer was found near Pergamino at 50-100 m. The aquifer recharge is local and produced by precipitation, being the main discharge towards rivers, streams or swamps.

Below, the Tertiary marine sediments of the "Mioceno Verde" Formation (Upper Miocene) contain very saline water, in general. Underlying, the "Mioceno Rojo" Formation of continental origin is placed with aquifer levels with variable salinity. This sedimentary sequence lies over the Mesozoic low permeability hydrogeological basement.

Yrigoyen (1975) showed through geological sections in transects situated at several zones of Buenos Aires Province, diffe- rent depths of the hydrogeological formations at close sites, which were attributed to the presence of faults that affected the more recent and shallow formations. Amato (1998) offered another interpretation related with the presence of paleochannels, produced by the Parana river, that generate great variations of thickness in the Puelche Formation within a few kilometers of distance. The isolines of the depth of its top have a regular and mild shape while the base has a more irregular form.

\section{GEOELECTRICAL PROSPECTING}

\section{VES methodology}

At the study zone of Pergamino-Arrecifes, a set of VES were carried out with an adequate distribution of sites in order to have a good description of the basin.

Eighteen VES were performed using the Schlumberger array (VES18-35) which constitute, with previous soundings of Sainato et al. (2003) (VES 1-17), a set of thirty five VES covering the whole area (see Figure 1). Well data were collected from SPAR (1999) at some places and some VES sites were located near them for geophysical interpretation (Figure 1). 
Table 1 - Geological and Hydrogeological setting.

\begin{tabular}{|c|l|}
\hline $\begin{array}{c}\text { Hydrogeological } \\
\text { formations }\end{array}$ & \multicolumn{1}{c|}{\begin{tabular}{c}
\multicolumn{1}{c}{ Geological and } \\
hydrogeological features
\end{tabular}} \\
\hline \multirow{5}{*}{ Pampeano } & $\begin{array}{l}\text { A sequence of permeable (sandy) } \\
\text { and impermeable (more clayey) } \\
\text { horizontally layered levels, it contains } \\
\text { the free aquifer and some deeper } \\
\text { semiconfined aquifers. } \\
\text { Thickness: between } 20 \text { and } 120 \mathrm{~m}\end{array}$ \\
\hline \multirow{5}{*}{ Puelche } & $\begin{array}{l}\text { Quartziferous yellowish sands, } \\
\text { of medium grain, with intercalation } \\
\text { of gravel. Thickness: } 10 \text { to } 25 \mathrm{~m} . \\
\text { The top is at } 50 \text { and } 100 \mathrm{~m} \text { depth. } \\
\text { Semiconfined aquifer with } \\
\text { bicarbonate sodium water. }\end{array}$ \\
\hline Mioceno Verde & $\begin{array}{l}\text { Grey-blue and green clays } \\
\text { with some intercalation of sand. } \\
\text { Marine origin. Thickness: between } \\
75 \text { and } 135 \mathrm{~m} \text {. Very saline water. }\end{array}$ \\
\hline Mioceno Rojo & $\begin{array}{l}\text { Sandstones and red clays with } \\
\text { an intercalation of ash and gypsum } \\
\text { of continental origin. Thickness: } \\
250 \mathrm{~m} \text {. Top at } 400-500 \mathrm{~m} \text { depth. } \\
\text { The water is generally salty. }\end{array}$ \\
\hline
\end{tabular}

For these soundings, distances $A B$ up to $1000 \mathrm{~m}$ at some sites and to $2000 \mathrm{~m}$ at other ones were reached. Models of electrical resistivity of the earth varying with depth (horizontally layered medium 1D), were proposed for each site of sounding, whose response of apparent resistivity fitted the experimental data in a least square sense. All sites were modeled with the $1 \mathrm{D}$ inversion code of Bobachev et al. (2001). Curves of observed apparent resistivity as a function of the half distance between current electrodes ( $A B / 2)$, together with the curves of the fitting model are shown in Figure 2, for the new sites (fitting error around $5 \%$ in average). The continuity of the different layers found in $1 \mathrm{D}$ models was analyzed along four transects $\mathrm{AA}^{\prime}, \mathrm{BB}^{\prime}, \mathrm{CC}^{\prime}, \mathrm{DD}$ ', crossing the Pergamino river at the central and eastern part of the zone (see Figure 1). Electrical sections from transects EE' and FF' were previously obtained by Sainato et al. (2003). Error interval for the model parameters was evaluated through equivalence principle analysis. The sounding interpretation was based on well data (SPAR, 1999) from towns near some VES sites: Acevedo (VES20), Anchorena (VES21), A. Dulce (VES24), Todd (VES29).

\section{VES Results and discussion}

Figure 3 shows the resistivity distribution below each site along transects $A A^{\prime}, B B^{\prime}, C C^{\prime}, D^{\prime}$. For all of them, the first layer represents the unsaturated zone while a decrease in resistivity for the second layer indicates the top of the Pampeano aquifer (water table). Below, the changes in resistivity are strongly influenced by water quality since there are no great changes in lithology. However, the presence of calcium carbonate intercalations ("tosca") (Sala \& Rojo, 1994) as nodules or continuous plates may increase the layer resistivities. A high conductivity layer is placed at depth at almost all the sites. Uncertainties in model parameters showed that the Pampeano resistivity has the lowest relative error (in average $1.7 \%$ ), being of about $6.3 \%$ for the depth to the highly conductive layer. The water table depth was the parameter determined with less accuracy.

\section{Transect AA'}

In this transect, unsaturated soil has resistivities varying between 14 and $23 \mathrm{ohm} \mathrm{m}$, with clayey-silty sediments according to well at site of VES20. The water table is between 2.5 and $5 \mathrm{~m}$ depth, and free groundwater has an average resistivity of $7.5 \mathrm{ohm} \mathrm{m}$ (with sandy-silty sediments) followed by a more resistive layer with larger content of silt and sand and lower water salinity. A highly conductive layer (near $3 \mathrm{ohm}$. $\mathrm{m}$ ) with larger content of clays (revealed by well data), is at approximately $25 \mathrm{~m}$ depth on the right margin and beyond $80 \mathrm{~m}$ depth at the left one. It may indicate the presence of the fresh-salty water interface.

\section{Transect BB'}

At this transect, the unsaturated zone (a set of thin layers with clayey-silty sediments according to wells at sites of VES21 and VES24) has an average resistivity of $14 \mathrm{ohm} \mathrm{m}$. Free groundwater has a resistivity of around $9 \mathrm{ohm}$. $\mathrm{m}$ at a depth between 2 and $12 \mathrm{~m}$. Underlying, there is a more resistive layer $(13.5 \mathrm{ohm} \mathrm{m}$ in average) predominantly of silty-loessic type with "tosca" according to wells. The highly conductive layer was found beyond 140 $\mathrm{m}$ depth at the right margin of Pergamino river and with variable depth (greater than $80 \mathrm{~m}$ approximately) at the left margin.

\section{Transect CC}

The water table is between 2 and $7 \mathrm{~m}$ depth and free groundwater has a resistivity of $9 \mathrm{ohm} \mathrm{m}$ in average. Below, layers with variable resistivity may be found at each site. Beneath site of VES27 and VES28 a more resistive layer may indicate the presence of calcium carbonate. Underlying, the highly conductive layer (less 

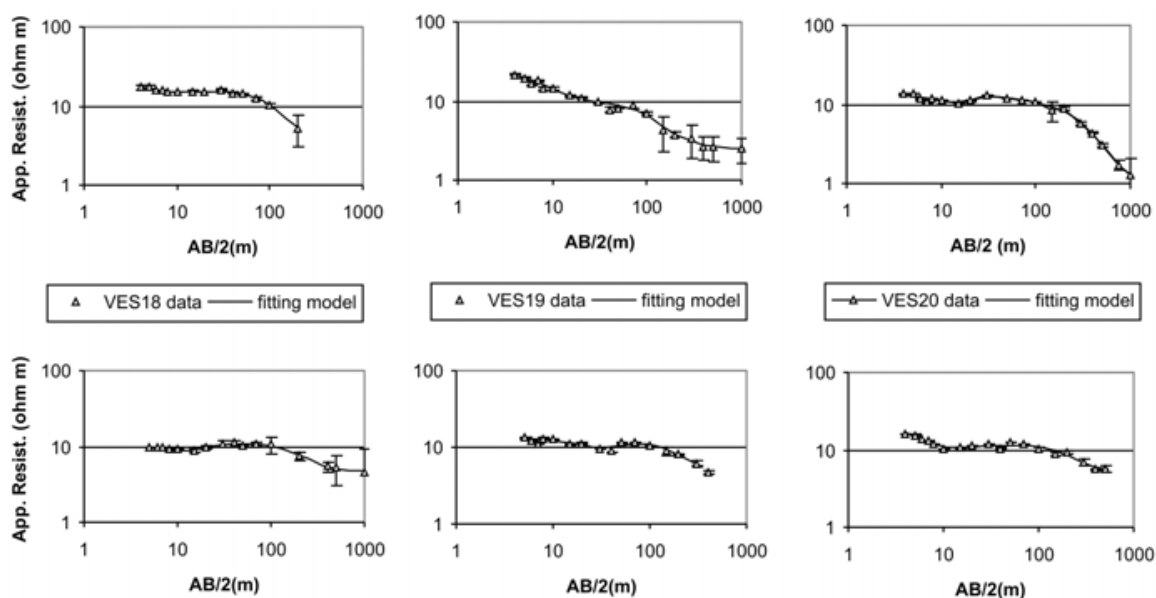

$\triangle$ VES21 data — fitting model

$\triangle$ VES22 data — fitting model

$\triangle$ VES23 data — fitting model
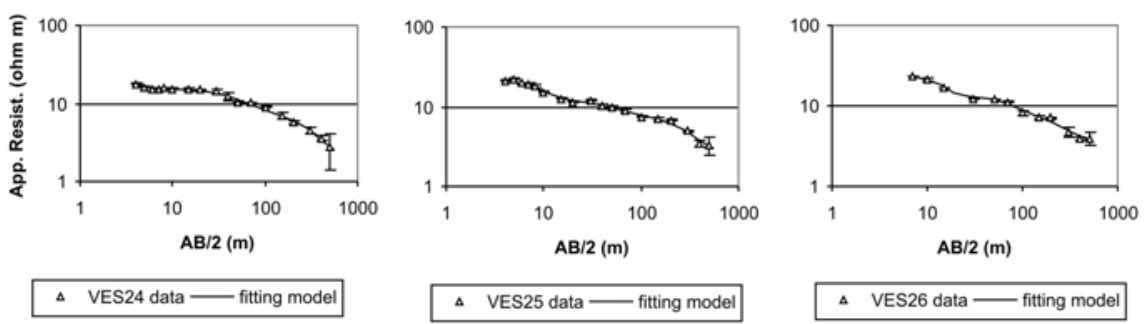

$\triangle$ VES26 data — - fitting model
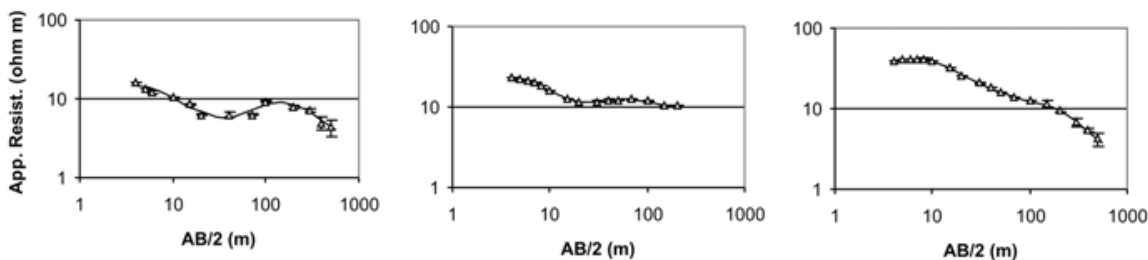

$\triangle \quad$ VES27 data - fitting model
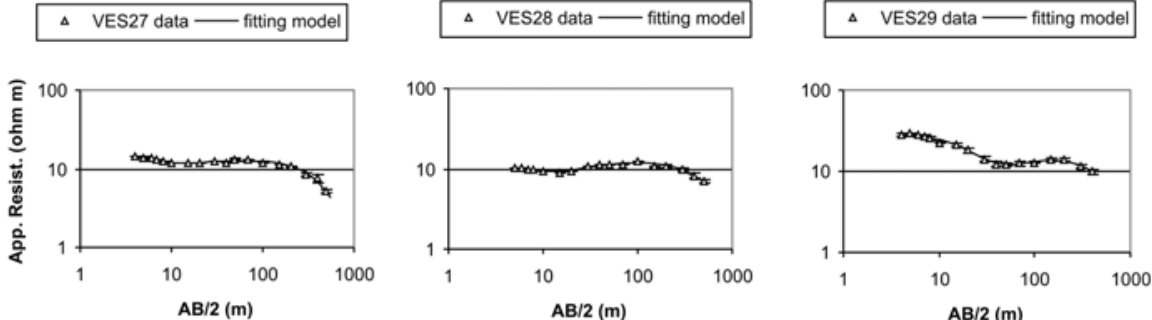

$\triangle$ VES30 data - fitting model
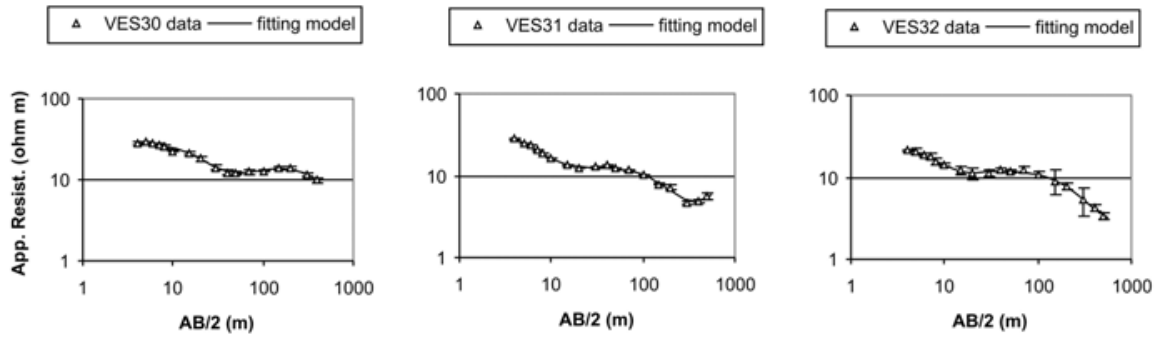

$\triangle \quad$ VES33 data - fitting model

$\triangle$ VES34 data - fitting model

$\triangle$ VES35 data — fitting model

Figure 2 - Fitting of 1D models to observed apparent resistivity curves for VES18 to VES35. 


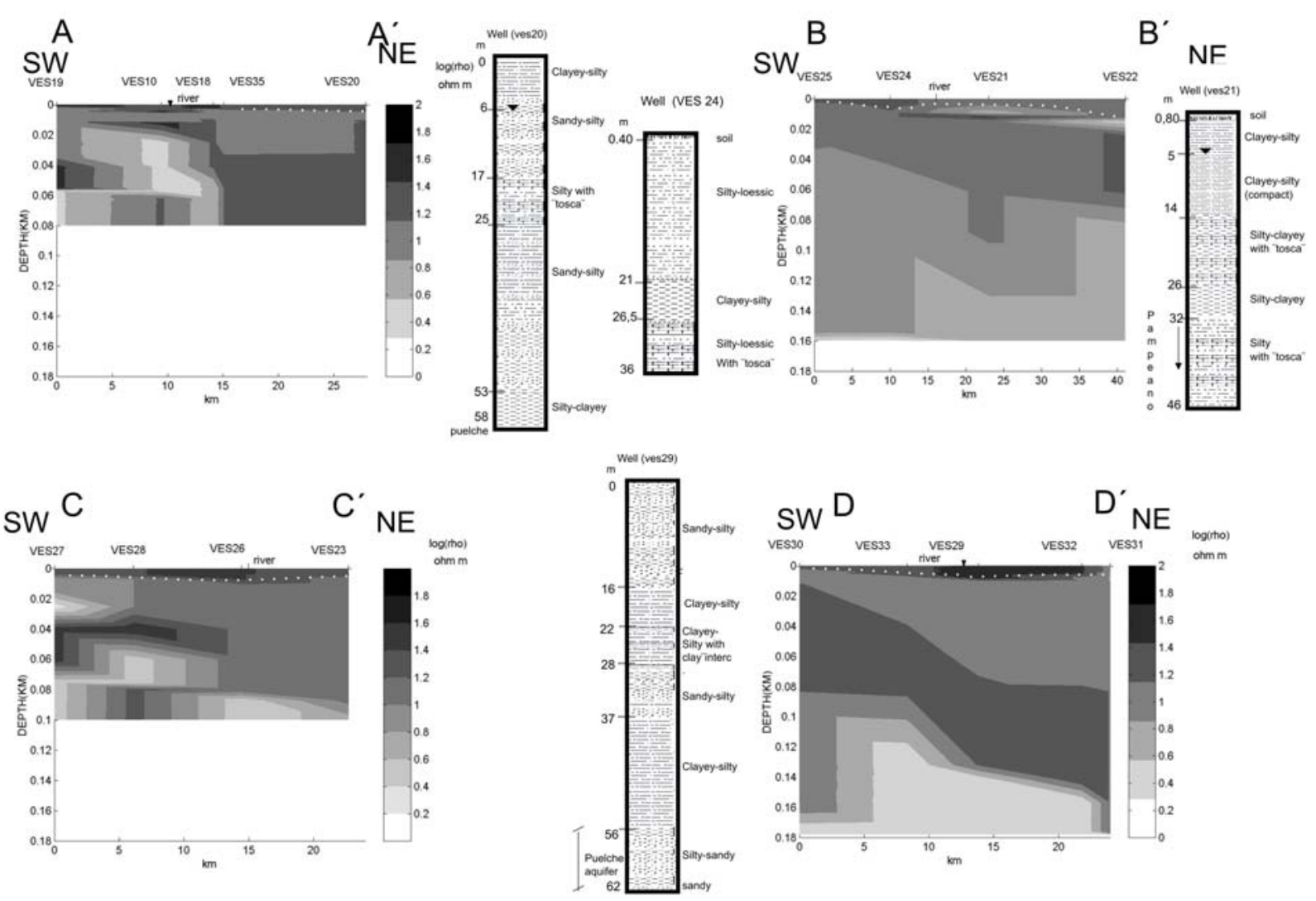

Figure 3 - Electrical resistivity sections obtained from VES models through transects AA', BB', CC' and DD'. Shading scale indicates log(rho: resistivity) in ohm m and the white dotted line is the limit between the unsaturated and saturated zone.

than $6 \mathrm{ohm} \mathrm{m}$ ) has variable depth at the SW (right margin) and it is placed beyond $80 \mathrm{~m}$ depth at the left margin.

\section{Transect DD'}

In this transect, unsaturated zone has resistivity values around 22 ohm $\mathrm{m}$ (with sandy-silty sediments according to well at site of VES29). Water table is between 3 and $8 \mathrm{~m}$ depth. Below, free groundwater correlates with a $10 \mathrm{ohm}$ m layer (clayey-silty sediments). The lower levels of the Pampeano aquifer, correlated with sandy-silty or clayey-silty sediments with intercalations of sands or "tosca", has a quite homogeneous resistivity around $12 \mathrm{ohm} \mathrm{m}$. From well data, the top of the Puelches sands is placed at $56 \mathrm{~m}$ depth, and up to $70 \mathrm{~m}$ depth with low salinity. In the geoelectrical model of VES29, a layer of approximately $12 \mathrm{ohm} \mathrm{m}$ of resistivity is present up to $154 \mathrm{~m}$ depth. Below, the top of the highly conductive layer must be associated with the fresh-salty water interface which in this case may be within the Puelches sands or even at the Miocene Formation.

Summarizing the results of these four transects, below the un- saturated zone, the Pampeano has the phreatic aquifer in its upper part being more conductive (may be with more contents of salts) than the lower levels which are exploited for agricultural and human use.

At greater depths, there is a highly conductive layer, associated with high salinity, whose top is placed at different depths at both margins. Low values of resistivity (less than $5 \mathrm{ohm} \mathrm{m}$ ) may be attributed to the increase of water salinization since the underlying Puelche aquifer is composed by sands.

It is well known, that at the west of the study zone, the Puelche aquifer may have salinity (Santa Cruz, 1987). The top of the conductive layer, then, may be the top of this aquifer and would represent the fresh-salty water interface (Sainato et al., 2003). Due to the lack of well information at such depth at the east of Pergamino, it is not possible to confirm wether the top of this conductive layer is placed within the Puelche aquifer or if it is the top of the Mioceno Verde Formation.

It may be observed that, in transects $A A^{\prime}$ and $B B^{\prime}$, the interface depth is different at both margins of the river. For transects 
$\mathrm{CC}^{\prime}$ and $\mathrm{DD}$ ' the difference in the interface depth between the right and left margin is around $20 \mathrm{~m}$. There is also a tendency for the interface in transects $\mathrm{EE}^{\prime}$ and $\mathrm{FF}$ ', to be slightly deeper at the left margin (Sainato et al., 2003).

This difference in the depth of the conductive layer may be an evidence of structural control. Geological cross-sections at different places at the Buenos Aires Province have shown fractures which have caused stratigraphic throw in the Mioceno Verde and the Mioceno Rojo Formations (Yrigoyen, 1975). This author suggests that there has been reactivation of some faults which affected the more recent and shallower formations.

Another interpretation (Amato, 1998) would be related to the existence of deep ancient channels (paleo channels) that produced variations in the thickness of the Puelches Formation between sites separated by a few kilometers. In addition, wells located at the city of Pergamino (Pergamino Municipality, personal communication) on both margins of the river have shown different depths to the fresh-salty water interface.

The top of this interface deepens, in general, to the NE and $S E$, as it is observed from the depths obtained from the transects.

\section{GEOSTATISTICAL ANALYSIS}

\section{Methodology. Theoretical background}

In order to analyse the spatial correlation of some aquifer properties and to obtain the areal distribution of them within the study area a geostatistical approach was applied.

The spatial dependence is described by the semivariograms (Trangmar et al., 1985). Let's be $z(x)$ and $z(x+h)$ the values of a property sampled at positions $x$ and $x+h$, being $h$ a distance, known as lag, which separates both positions. The semivariance is defined as

$$
\gamma(h)=\frac{1}{2 n(h)} \sum_{i=1}^{n(h)}\left[z\left(x_{i}\right)-z\left(x_{i}+h\right)\right]^{2}
$$

where $n(h)$ is the number of pairs of observations separated by a distance of $h$. The maximum lag $h$ used for the semivariance calculation is usually taken as half the maximum dimension of the study area.

The semivariogram, which is the plot of the semivariance versus $h$, in some cases increases with $h$ reaching an asymptotic value (sill) at a distance $h$ equal to the so called range $a$. Values of the properties at sites separated by a distance shorter than the range will be spatially correlated. The range depends on the scale of the study and on the property evaluated. The value of the semivariogram when $h=0$ is the nugget variance and is a measure of the experimental error or the microvariability of the property not detected at the sample distance. When the sill is equal to the nugget variance, the variable is considered to be spatially independent and aleatory (pure nugget effect). The nugget variance expressed as a percentage of the sill (N/S\%) allows a relative evaluation of the nugget effect in the analysed property. Cambardella et al. (1994) used this relationship to define different types of spatial dependence of soil variables: if the rate is less than $25 \%$ the variable is considered strongly spatially dependent, if it lies between 25 and $75 \%$ the variable is moderately dependent while if it is greater than $75 \%$ it is considered weakly spatially dependent.

Aquifer properties, such as the bulk resistivity of the Pampeano aquifer, the water table level and the depth of the fresh-salty water interface were supposed to have a spatial correlation. Semivariograms were estimated for these properties modelling them, using Geo-EAS (1988) software, in order to obtain the parameters: range, sill and nugget variance for evaluating the spatial correlation of these variables.

The areal distribution of these properties may be considered by an interpolation called kriging. The range of the semivariogram is associated with the maximum distance for this interpolation. The kriging provides an unbiased estimate of minimum variance where the value of the property at each point in a grid is estimated as a lineal combination of neighbouring sites.

If $z\left(x_{1}\right), z\left(x_{2}\right), \ldots z\left(x_{n}\right)$ are the values of the property measured at $x_{i}$, with $i=1 \ldots n$, the estimation of the value at a point $x$ is:

$$
z(x)=\lambda_{1} z\left(x_{1}\right)+\lambda_{2} z\left(x_{2}\right)+\ldots \lambda_{n} z\left(x_{n}\right)
$$

The coefficients $\lambda_{i}$ are calculated searching an unbiased estimator of $z$ with minimum variance (Webster, 1985).

Maps of isolines of the properties previously mentioned were carried out taking into account their semivariogram parameters. A cross validation analysis of the krigged results was performed to evaluate the accuracy of the estimations. Figure 4 shows the semivariograms for:

- the bulk resistivity of the Pampeano aquifer obtained from VES models at depths where water extraction takes place, according to well information (a).

- the depth of the fresh-salty water interface from surface (b).

- the water table level in meters (a.s.l.) (c) 


\section{Bulk resistivity}

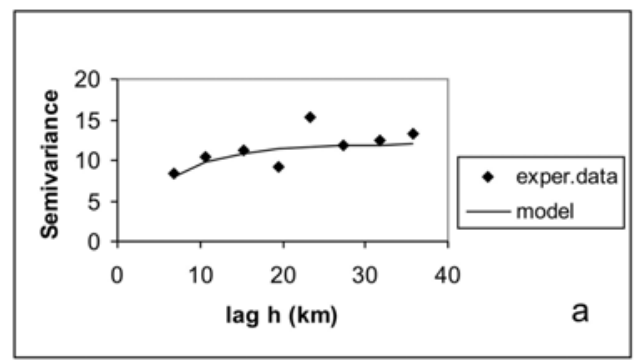

Interface

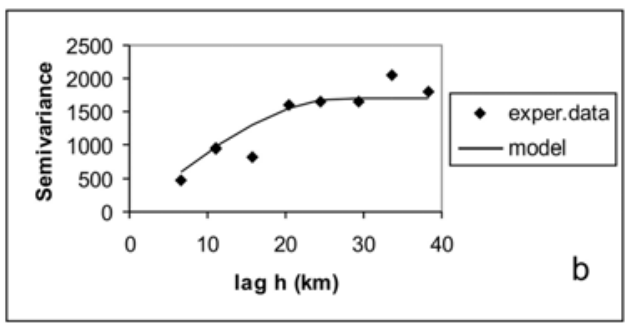

Water table level

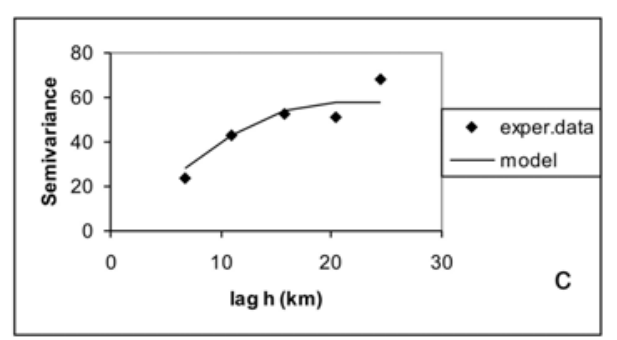

Figure 4 - a. Semivariogram of bulk resistivity of the Pampeano aquifer (at nearly $25-30 \mathrm{~m}$ depth ) obtained from VES and fitting model. b. Semivariogram of depth to fresh-salty water interface obtained from VES and fitting model. c. Semivariogram of water table level (a.s. I.) obtained from VES and fitting model.

\section{Geostatistical results and discussion applied to some aquifer characteristics}

Table 2 summarizes the parameters obtained from the modelling of semivariograms.

Table 2 - Parameters obtained from modeling of semivariograms.

\begin{tabular}{|c|c|c|c|}
\hline Property & Nugget variance & Sill & Range \\
\hline $\begin{array}{c}\text { Bulk } \\
\text { resistivity of } \\
\text { Pampeano aquifer }\end{array}$ & $1(\text { ohm m})^{2}$ & $12(0 \mathrm{hm} \mathrm{m})^{2}$ & $20 \mathrm{~km}$ \\
\hline $\begin{array}{c}\text { Depth to } \\
\text { fresh-salty } \\
\text { water interface }\end{array}$ & $38 \mathrm{~m}^{2}$ & $1813 \mathrm{~m}^{2}$ & $27.5 \mathrm{~km}$ \\
\hline $\begin{array}{c}\text { Water } \\
\text { table level }\end{array}$ & 0 & $58 \mathrm{~m}^{2}$ & $20 \mathrm{~km}$ \\
\hline
\end{tabular}

The parameters for the bulk resistivity of the Pampeano aquifer were obtained with a spherical model (fitting error of $1.9 \%$ ), with a range of $20 \mathrm{Km}$, and a rate between nugget variance and sill (N/S\%) of about $8 \%$, which means a strong spatial dependence, according to Cambardella et al. (1994).

For the depth of the fresh-saline water interface, the spherical fitting (fitting error $2.7 \%$ ) gave a range of $27.5 \mathrm{~km}$ and a rate $\mathrm{N} / \mathrm{S} \%$ of about $2 \%$, meaning a very strong spatial dependence of this depth.

For the water table level an exponential fitting (fitting error $1.4 \%$ ) showed a range of $20 \mathrm{Km}$, with very little $\mathrm{N} / \mathrm{S} \%$ rate indicating a strong spatial dependence of this variable.

The relationship between the bulk conductivity of a layer and the water conductivity filling the pores is stated through several equations being the most commonly known as the Archie's law (Archie, 1942):

$$
\sigma_{b}=\sigma_{w} \Phi^{m}+\sigma_{\text {clay }}
$$

for a completely saturated soil in the presence of clay.

$\sigma_{b}$ is the bulk conductivity of the layer.

$\sigma_{w}$ is the water conductivity.

$\Phi$ is the porosity.

$\sigma_{\text {clay }}$ is the clay conductivity.

$m$ is a factor depending on the shape of the sediments. A value around 1.8-2 is appropriate for porosities between 10 and $30 \%$ (McNeill, 1990).

Taking into account the bulk conductivity for the Pampeano aquifer obtained from the VES models and the water conductivity measured on well samples near them, the correlation between these variables was estimated. The linear regression corresponds to Archie's law, where a value of porosity may be inferred from its slope. There was no significative linear correlation between $\sigma_{b}$ and $\sigma_{w}$ when the whole set of data were involved. However, considering only the sites situated at the west of the zone of deepening of the fresh-salty water interface ( $12 \mathrm{~km}$ to the west of Arrecifes city and about $23 \mathrm{~km}$ to the west of the eastern limit of the study zone of Figure 1), the correlation increased. The linear regression, indicated a value of $\sigma_{\text {clay }}$ around $318,94 \mu \mathrm{S} / \mathrm{cm}$ with $R^{2}=0,45$ (Figure 5.a.). A porosity around $46 \%$, for the Pampeano aquifer, may be inferred from the slope. This estimation is just an inference but the value, somewhat overestimated, is in the range for clayey sediments. The correlation between $\sigma_{b}$ and TDS (Total dissolved solids) is shown in Figure 5.b. $\left(R^{2}=0.51\right)$, being the $\sigma_{b}$ a moderate indicator of groundwater mineralization.

Figure 6 a,b,c shows the areal distribution of bulk resistivity, depth to interface and water table level above sea level, respecti- 
$\sigma_{\mathrm{b}}(\mu \mathrm{S} / \mathrm{cm})$

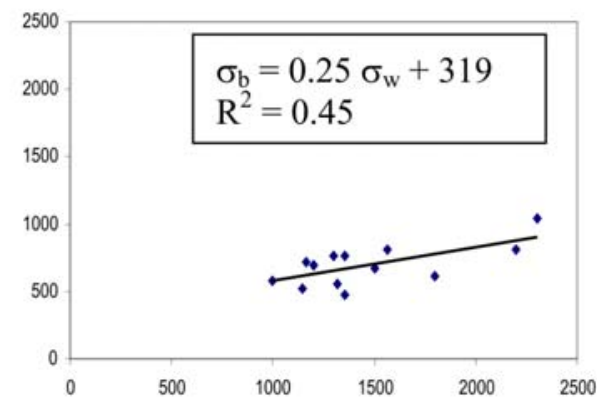

a.

$$
\sigma_{\mathrm{w}}(\mu \mathrm{S} / \mathrm{cm})
$$

\section{$\sigma_{\mathrm{b}}(\mu \mathrm{S} / \mathrm{cm})$}

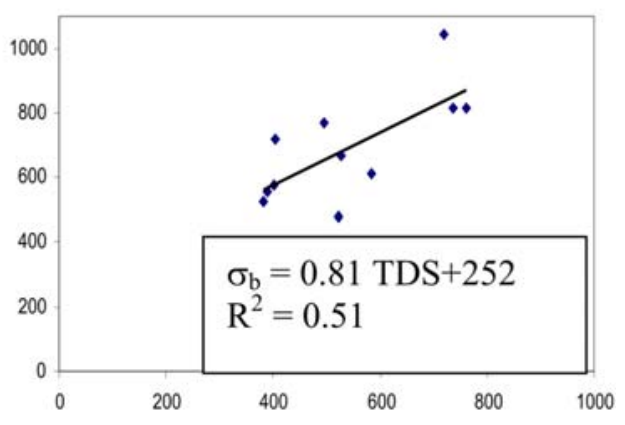

b.

TDS (ppm)

Figure 5 - a. Linear regression between bulk conductivity $\sigma_{b}$ of the Pampeano aquifer and water conductivity $\sigma_{w}$. Fitting equation is shown. b. Linear regression between bulk conductivity $\sigma_{b}$ of the Pampeano aquifer and TDS (Total dissolved solids) in water. Fitting equation is shown.

vely, obtained from kriging interpolation (Geo-EAS, 1988).

Figure $7 \mathrm{a}, \mathrm{b}, \mathrm{c}$ are the plots of the estimated values obtained by kriging and the observed data, resulting from cross validation analysis of aquifer properties. As it has been shown before no correlation between bulk resistivity and groundwater conductivity could be achieved including sites near Arrecifes city. These sites were excluded from the kriging processing (Figure 6a). The distribution of bulk resistivity of the Pampeano aquifer shows a clear trend with values around $8 \mathrm{ohm} \mathrm{m}$ at the west area increasing towards the east up to $18 \mathrm{ohm} \mathrm{m}$. The accuracy of the kriging interpolation for bulk resistivity is not good for some sites where values are over or sub estimated (Figure 7a).

At most of the sites at the SE zone, the interface depth was sub estimated (Figure 7b), and even if the observed data indicate greater depths for the interface, deepening to the east, the kriging interpolation is shown with dotted line (Figure 6b) since it has low accuracy. It seems that interpolation does not fit data when changes are very strong. The depth of fresh-saline water interface deepens to the SE, with a remarkable difference between the values around $40 \mathrm{~m}$ near Pergamino city and the ones obtained near Arrecifes $(140 \mathrm{~m})$. It shows a steep deepening of this interface, along a short distance (high gradient) at approximately $12 \mathrm{~km}$ to the west of Arrecifes city (Meridian $60^{\circ} 10^{\prime} \mathrm{W}$ ).

Estimated values of water table level are in agreement with observed data (Figure 7c). The distribution of water table level shows a clear decrease to the SE, accompanying the topography. This implies a free groundwater flow from NO to SE with some local components to the Pergamino river. Costa et al. (2002) found at the southern part of Bs. As. Province that groundwater flow direction in a multilayer aquifer coincides with free groundwater flow and with the direction of river flows.

The area at the west of Arrecifes city may be called a transition zone for the correlation of electrical conductivity and it is the same place where the fresh-salty water interface deepens abruptly. The transition zone also shows a higher hydraulic gradient of free aquifer (Figure 6c). Yechieli et al. (2001), in a multilayer aquifer, associated a higher slope of the interface, near fault zones, with a higher piezometric gradient. Then, if the transition zone of this study was related with a fault zone, the interface behaviour might be a sign of a higher hydraulic gradient of deeper aquifers. In addition, if a higher hydraulic gradient of free aquifer is present at this zone it may be thought that the distribution of groundwater flow may be similar for both of them, the phreatic and the deeper multilayer aquifers. Sala (1975) had previously suggested the idea that the morphology of the water table must reflect the general piezometry of the deeper aquifers and these results may be an evidence of this fact.

\section{CONCLUSIONS}

The variability in the stratigraphic sequence and in groundwater salinity was investigated through transects of Vertical Electrical Soundings. The depth to fresh-salty groundwater interface, a limit to the exploitation wells, does not have a regular or smooth shape. The top of the conductive layer, related to the interface, deepens towards the left margin of the Pergamino river and to the $\mathrm{SE}$, abruptly at around $12 \mathrm{~km}$ to the west $\left(60^{\circ} 10^{\prime} \mathrm{W}\right)$ of Arrecifes city; this location may be called a transition zone. The thickness of the Pampeano aquifer with low salinity, potentially exploitable, 

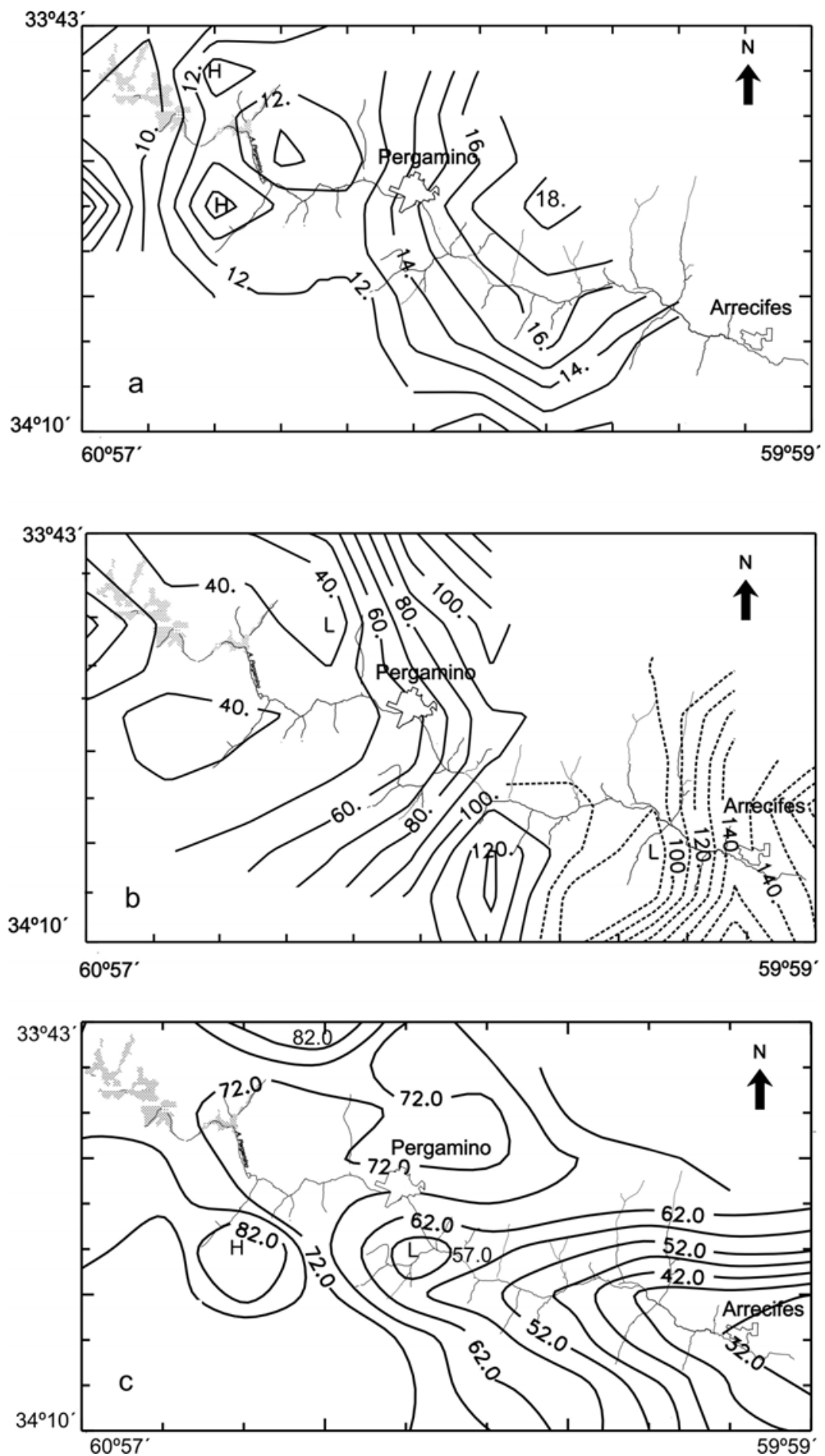

Figure 6 - a. Distribution of bulk resistivity of the Pampeano aquifer (at nearly 25-30m depth ) interpolated by kriging using parameters of the semivariogram model. Isolines labels are in ohm $\mathrm{m}$. b. Distribution of depth in meters to fresh-salty water interface interpolated by kriging using parameters of the semivariogram model. Isoline labels are in $\mathrm{m}$ from surface. Kriging interpolation with dotted line means lower accuracy. c. Distribution of water table level in $\mathrm{m}$ (a.s.l.) interpolated by kriging using parameters of the semivariogram model. 
is larger at the Arrecifes zone than at Pergamino.
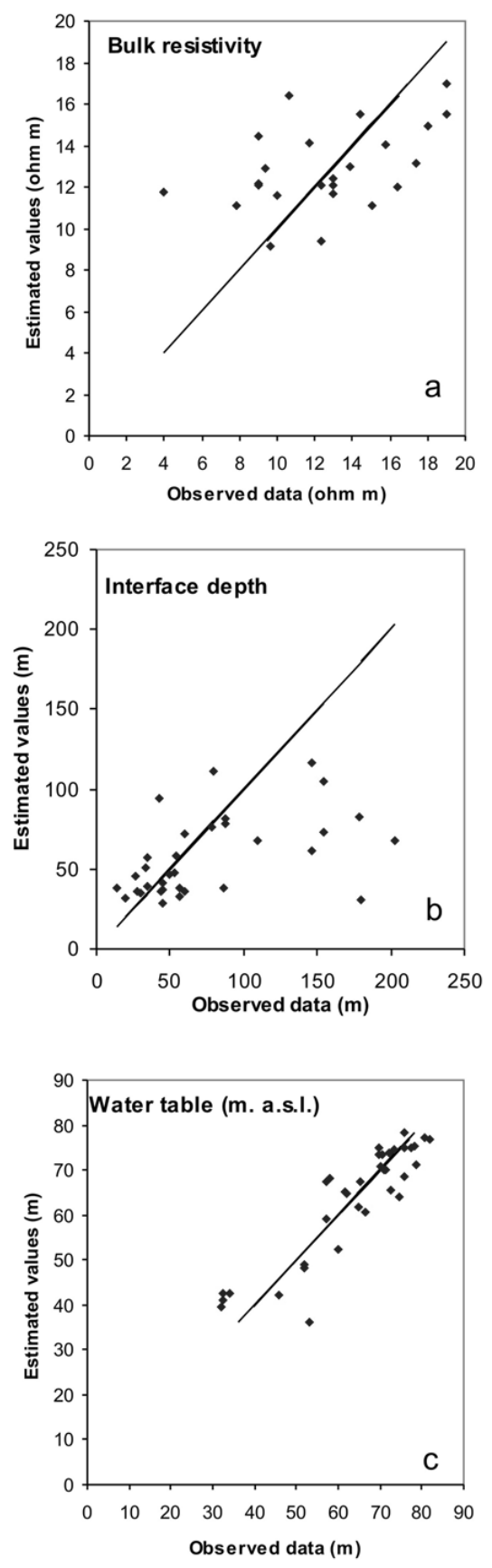

Figure 7 - Crossvalidation analysis. Plots of the estimated values obtained by kriging and the observed data, together with the line of slope one. $\mathbf{a}$. for bulk resistivity (ohm.m). b. for interface depth (m). c. for water table level (m).

The spatial distribution of some aquifer properties was evaluated by means of geostatistical analysis. The electrical resistivity of the Pampeano aquifer was rather homogeneous at the centre of the study area, with a slight increase from west to east, decreasing groundwater salinization. Free groundwater has higher values of conductivity than the deeper levels of the Pampeano aquifer. The water table level has an homogeneous behaviour at the west of Pergamino city. It may be observed an increase of its hydraulic gradient coinciding with the transition zone where the depth of the fresh-salty water interface also increased. The direction of free groundwater flow is NW-SE and deeper multilayer aquifers might have a similar flow pattern.

\section{ACKNOWLEDGEMENTS}

This work was financially supported by the University of Buenos Aires. The authors thank Ing. José Luis Monsó for helping with the Portuguese translation.

\section{REFERENCES}

AMATO S. 1998. Caracterización morfológica de la formación Puelches en el ámbito de la Provincia de Buenos Aires, Argentina. Actas de X Congreso Latinoamericano de Geología y VI Congreso Nacional de Geología Económica, Argentina, 1: 214-219.

ARCHIE GE. 1942. The electrical resistivity log as an aid in determining some reservoir characteristics. Transactions of the American Institute of Mining, Metallurgical and Petroleum Engineering, 146-154.

BOBACHEV A, MODIN I \& SHEVNIN V. 2001. IPI2Win software. Geoscan-M Ltd. Moscow State University. Russia.

CAMBARDELLA C, MOORMAN T, NOVAK J, PARKIN T, TURCO R \& KONOPKA A. 1994. Field-scale variability of soil properties in Central lowa soils. Soil Science of American Journal, 58(5): 1501-1511.

COSTA JL, MASSONE H, MARTINEZ D, SUERO E, VIDAL C \& BEDMAR F. 2002. Nitrate contamination of a rural aquifer and accumulation in the unsaturated zone. Agricultural water management, 57: 33-47.

GE0-EAS. Geoestatistical Environmental Assessment Software. 1988. EPA, Systems laboratory, Las Vegas - USA.

McNEILL JD. 1990. Use of electromagnetic methods for groundwater studies. In Geotechnical and Environmental geophysics. Review and Tutorial, Society of Exploration Geophysicists 1: 191-218.

MARINHO JML \& VASCONCELOS SMS. 2001. Imageamento geoelétrico de colunas e secções de modelos 1-D utilizando técnicas geoestatísticas. Proceedings of the $7^{\text {th }}$ International Congress of the Brazilian Geophysical Society. CD-ROM. Salvador. Brasil, 100-103.

SAINATO C, POMPOSIELLO MC, LANDINI A, GALINDO G \& MALLEVILLE H. 2000. The hydrogeological sections of the Pergamino basin (Bs. As. Province, Argentina): Audiomagnetotelluric and geochemical results. Brazilian Journal of Geophysics, 18(2): 187-200.

SAINATO C, GALINDO G, POMPOSIELLO MC, MALLEVILLE H, DE ABELLEYRA D \& LOSINNO B. 2003. Electrical conductivity and depth 
of groundwater at the Pergamino zone (Buenos Aires Province, Argentina) through Vertical Electrical Soundings and Geostatistical analysis. J. of South American Earth Sciences, 16(2): 177-186.

SALA JM. 1969. El agua subterránea en el NE de la Prov. De Bs. As., Argentina. In: Actas de la Reunión Geológica del Agua subterránea. CIC (Eds.). La Plata. Prov. de Bs. As. Argentina, 25-49.

SALA JM. 1975. Recursos hídricos. Relatorio Geología de la Pcia. de Bs. As. VI Congreso Geológico Argentino. Bahía Blanca. Argentina.

SALA JM, GONZALEZ N \& KRUSE E. 1983. Generalización hidrológica de la Prov. De Bs. As. In: UNESCO (Eds.). Coloquio internacional sobre hidrología de grandes Ilanuras, 973-1009.

SALA JM \& ROJO M. 1994. Pasado, presente y futuro de la hidrología subterránea en la Provincia de Buenos Aires, Argentina. In: Temas actuales de la hidrología subterránea. Consejo Federal de Inversiones. Universidad Nacional de Mar del Plata. Argentina.

SANTA CRUZ J. 1987. Caracterización del recurso hídrico subterráneo con miras al riego suplementario en la región NNE-maicera típica- de la Pcia. de Bs. As. Informe del Instituto Interamericano de Cooperación para la Agricultura en convenio con Secretaría de Agricultura, Ganadería y Pesca (Argentina). Documento de trabajo, 15: 161

SANTA CRUZ J. 1994. Aspectos hidrogeológicos e interpretación de una nueva característica formacional de subyacencia del acuífero Puelches, Pcia. de Bs. As., Argentina. In: BOCANEGRA E \& RAPACCINI A. (Eds.). Temas actuales de la hidrología subterránea. Consejo Federal de Inversiones. Universidad Nacional de Mar del Plata. Argentina, 261-272.
SANTA CRUZ J \& SILVA BUSSO A. 1995. Disponibilidad del agua subterránea para riego complementario en las Pcias. de Bs. As., E. Ríos Córdoba y Santa Fe. Programa de Servicios Agrícolas provinciales. Secretaría de Agricultura, Ganadería y Pesca (Argentina), 55 pp.

SPAR. 1999. Servicio Provincial de Agua Rural. Dirección de Hidráulica, Pcia. de Bs. As.

SUN NZ, JENG MC \& YEH WW. 1995. A proposed geological parameterization method for parameter identification in three-dimensional groundwater modeling. Water Resources Research, 31(1): 89-102.

TERUGGI M. 1957. Nature and origin of Argentine Loess. Journal of Sedimentary Petrology, 27(3): 322-332.

TRANGMAR B, YOST RS \& UEHARA G. 1985. Applications of geostatistics to spatial studies of soil properties. Advances in Agronomy, 38: 45-94.

WEBSTER R. 1985. Quantitative spatial analysis of soil in the field. In: STEWART BA (Ed.). Advance in soil science. New York: Springer-Verlag, $3(1): 1-70$

YECHIELI Y, KAFRI U, GOLDMAN M \& VOSS C. 2001. Factors controlling the configuration of the fresh-saline water interface in the Dead Sea coastal aquifers: synthesis of TDEM surveys and numerical groundwater modeling. Hydrogeology Journal, 9(4): 367-377.

YRIGOYEN M. 1975. Geología del subsuelo y plataforma continental. Relatorio de la Pcia. de Bs. As., Actas del VI Congreso Geológico Argentino, B. Blanca, Argentina, 139-168.

\section{NOTES ABOUT THE AUTHORS}

Claudia M. Sainato. Dr. in Physics graduated at the University of Buenos Aires. Argentina. Associate Professor at the School of Agronomy of the University of Buenos Aires. Teaching activities for twenty two years. Now, in charge of graduate and post graduate courses. Working at research projects on geophysics for twenty years. From 1996 doing research in geophysics applied to groundwater exploration and environmental studies. Twenty six papers published in international and regional journals and more than fifteen papers published in proceedings of scientific congresses. More than thirty presentations in international and regional congresses. Member of the Working Group Committee of Electromagnetic Induction in the Earth (IAGA).

Beatriz N. Losinno. Physicist and Magister Scientiae in Soil Science. University of Buenos Aires. Argentina. Teaching position at the School of Agronomy of the University of Buenos Aires: Chief of Practical Courses. Working at research projects on geophysics for ten years. Current research: geophysics applied to groundwater exploration and environmental studies. Sixteen publications in international and regional journals and proceedings of scientific congresses. Sixteen presentations in international and regional congresses. Member of the Argentine Association of Soil Science. 